\title{
Effect of rumen-protected methionine on feed intake, milk production, true milk protein concentration, and true milk protein yield, and the factors that influence these effects: A meta-analysis
}

\author{
R. A. Patton ${ }^{1}$ \\ Nittany Dairy Nutrition Inc., Mifflinburg, PA 17844
}

\begin{abstract}
A meta-analysis of published studies was used to investigate the effect of rumen-protected methionine (RPM) added to the diets of lactating dairy cattle on dry matter intake, milk production, true milk protein (TMP) production, and milk fat yield. Differences in responses between 2 commonly used RPM products, Mepron (Evonik Industries, Hanau, Germany) and Smartamine (Adisseo, Antony, France), were investigated as well as dietary and animal factors that could influence responses. Diets were coded with respect to the amino acid (AA) deficiency of the control diet as predicted by the AminoCow model (version 3.5.2, http://www.makemilknotmanure.com/aminocow.php; $0=$ no AA deficiency, $1=$ Met deficiency, $2=$ Met and Lys deficiency, $3=$ Met and Lys plus at least 1 other AA deficiency) to test the effect of AA deficiencies on RPM response. Thirty-five studies were identified, 17 studies evaluating Mepron, 18 studies evaluating Smartamine, and 1 study evaluating both. This permitted 75 dietary comparisons between control and RPM-added diets. Diets were entered into the AminoCow and the 2001 National Research Council models to compare predictions of Met, Lys, and metabolizable protein (MP) flow. Mean Met and Lys in diets where RPM was fed were estimated to be 2.35 and $6.33 \%$ of MP, respectively. Predictions of flows between models were similar. Overall, RPM addition to diets increased production of TMP, both as percentage $(0.07 \%)$ and yield $(27 \mathrm{~g} / \mathrm{d})$. Dry matter intake and milk fat percentage were slightly decreased, whereas milk production was slightly increased. Differences between products were detected for all production variables, with Mepron-fed cows producing less TMP percentage but greater milk production, resulting in twice as much TMP yield. Milk protein response to RPM was not related to predicted AA deficiency, calculated Met deficiency, or Met as a percentage of MP. Other dietary factors, including Lys
\end{abstract}

Received September 2, 2009.

Accepted January 21, 2010.

${ }^{1}$ Corresponding author: nittnut@aol.com flow (g/d), Lys as percentage of MP, neutral detergent fiber percentage, crude protein percentage, or energy balance, had no detectable effects on TMP response. When cows with a predicted positive AA balance were fed RPM, milk production increased, but when AA balance was negative, milk production decreased. Amount of RPM added to the diet was not correlated to TMP response. This study does not support the necessity of a high Lys level as a prerequisite to obtaining a TMP response to feeding RPM or the MP requirement suggested by the National Research Council model (2001). However, more dose-response studies over a wide range of milk production and dietary regimens will be required to more clearly establish AA requirements and to predict responses to RPM supplementation.

Key words: dairy cow, rumen-protected methionine, milk protein

\section{INTRODUCTION}

The factors that influence production of milk protein are of considerable interest to dairy farmers and dairy cattle nutritionists because of the emphasis put on protein production by many pricing systems. Rumenprotected methionine (RPM) has been promoted as a product that significantly increases milk protein percentage (Rulquin and Delaby, 1997; Socha et al., 2005 ), the most often observed production response to an increase in dietary Met (Schwab et al., 2001). However, results have not been consistent. Milk protein percentage has increased in most studies (Chilliard and Doreau, 1997; Rulquin and Delaby, 1997; Kowalski et al., 2003; Leonardi et al., 2003; Berthiaume et al., 2006, for example) when RPM has been supplemented, but has been unaffected in several other studies (Papas et al., 1984a; Krober et al., 2001; Younge et al., 2001; Davidson et al., 2008). Yet, an increase in milk protein percentage as a response to feeding RPM has resulted in a significant increase in milk protein yield in only a few studies (Armentano et al., 1997; Rulquin and Delaby, 1997; Samuelson et al., 2001; Lara et al., 2006) and was actually negative in one study (Benefield et al., 2009). Additionally, some studies have reported increased milk 
fat percentage (Overton et al., 1998; Samuelson et al., 2001), whereas several more have found an increase in milk fat yield (Overton et al., 1996; Schmidt et al., 1999; Krober et al., 2000), and other studies have found a significant decline in milk fat yield (Chilliard and Doreau, 1997; Socha et al., 2005). Whereas in most studies milk yield has not changed in response to RPM, several studies reported increased production (Samuelson et al., 2001; Lara et al., 2006), and several authors reported a significantly decreased milk yield (Chilliard and Doreau, 1997; Rulquin and Delaby, 1997; Benefield et al., 2009).

Two RPM products have been extensively studied in the literature: Mepron (Evonik Industries, Hanau, Germany) and Smartamine (Adisseo, Antony, France). Studies based on Met concentration of jugular serum have concluded that Smartamine was a much more effective Met supplement than was Mepron (Blum et al., 1999; Sudekum et al., 2004), but conclusive proof is lacking. Schwab et al. (2001) have suggested that changes in milk protein percentage may be a more sensitive method of determining effectiveness of RPM supplementation. Although milk protein percentage may be important, increases in grams of milk protein secreted may be a more sensitive measure of Met utilization than milk protein percentage because of possible declines in milk production due to feeding RPM. NRC (2001) has proposed that a ratio of Met to MP (Met as $\%$ of MP) is the correct measure of Met adequacy. The committee has suggested that $2.54 \%$ of MP should be Met. However, Lapierre et al. (2006) suggested that because of competing metabolic fates, expressing requirements as ratios lacks sufficient precision. Patton (2009) suggested that adding gram quantities of RPM to fulfill the Met requirement, irrespective of MP percentage, was the proper method to describe requirements for practical applications. Because of these seemingly contradictory factors, nutritionists and dairy farmers are confused about the effectiveness of feeding RPM, are distrustful of products, and have lost confidence in requirement specifications.

A large amount of data regarding the use of RPM has been published in numerous journals. Meta-analysis has been used to study effects of Lys and Met from both feeding and infusion experiments (Vyas and Erdman, 2009). It was thought that similar techniques could be used to study the effects of RPM alone to correct erroneous impressions of products and how they function, as well as to provide insight into circumstances under which they would elicit the most favorable responses. Therefore, the objectives of this study were 1) to investigate the effect of RPM on changes in DMI, milk yield, milk protein percentage, and milk protein yield;
2) to elucidate any differences in performance between 2 commercially available RPM sources; and 3) to discover factors that might influence any such response including amounts of Met and Lys. A secondary objective was to evaluate the differences in prediction of Met and Lys flows between the AminoCow (http://www. makemilknotmanure.com/aminocow.php) and NRC (2001) models.

\section{MATERIALS AND METHODS}

A literature search using PubMed, Agricola, and Google Scholar search engines was initially undertaken to identify studies in which either Mepron or Smartamine was fed to lactating dairy cows. This search was augmented by a search of the Pennsylvania State University CAT system. All searches were done using the key words "rumen protected methionine," "Smartamine," and "Mepron." After removing studies that were done with nonlactating cattle or species other than cattle, 129 studies provided the initial database. Because Smartamine had the same reported percentage of coating and DL-Met content, it was considered essentially the same product whether produced by the Eastman Chemical Division of Eastman Kodak (Kingsport, TN), Rhone-Poulenc Animal Nutrition (Commentry, France), or Adisseo. Therefore, all studies using these products were grouped as Smartamine.

\section{Selection, Inclusion, and Exclusion Criteria}

Only full studies that were published in refereed journals were chosen because of complete diet description (i.e., abstracts and review articles were not considered); 44 studies were removed for these reasons. Also rejected were 6 studies that used infusion as all or part of the treatment. Another 18 studies were removed because they used RPM in combination with rumen-protected lysine or other Lys sources and the effects of RPM alone could not be tested. Seventeen studies were eliminated because they employed other RPM products. To identify dietary factors that might affect RPM responses, studies must have included sufficient data to allow reconstruction of the experimental diet and must have provided information on DMI, milk production, and milk protein production, either as protein yield or as milk protein percentage. Five studies were removed because milk production was not reported, 2 were removed because dry matter intake was not reported, and 1 was removed because of incomplete characterization of the concentrate portion of the diet. This left a database of 36 studies. Because comparisons were between a control diet and a treatment diet that differed only 
in the inclusion of RPM, not all diets from all studies were used.

\section{Model Entry and Variables Evaluated}

To compare predicted supply of AA among diets and between models, diets were entered into the AminoCow (AC) Dairy Ration Evaluator, version 3.5.2 (Evonik Industries; http://www.makemilknotmanure.com/ aminocow.php) and the NRC (2001) model. The RPM data for use in both models were obtained from the respective manufacturers (for Mepron, W. Heimbeck, Evonik Industries; for Smartamine, B. Sloan, Adisseo; personal communications). Identical carbohydrate fractions including lignin, protein fractions including NDFand ADF-bound CP, fat, and ash were entered into both models to determine differences in model predictions. The same CP was entered into both models, but protein fractions, RUP, microbial protein, and amino acid composition of these fractions were determined by model defaults. In all cases, analyses of individual feed ingredients as reported were entered into the programs when available. When nutrient analysis of ingredients was not reported, analyses of forages were adjusted to agree with the reported ration content of $\mathrm{CP}$, NDF, ether extract, and ash (as percentage of DM). When ingredient analyses were unreported, $\mathrm{AC}$ defaults for acid detergent lignin, NDF-bound CP, and ADF-bound $\mathrm{CP}$ were used. Employed for the AC model was the option to reduce the prediction of microbial protein synthesis if RDP is deficient. The following variables were evaluated: MP, MP balance (defined as the difference between requirement and estimated supply), grams of Met flow, Met as a percentage of MP, grams of Lys flow, and Lys as percentage of MP. Other nutrients were identical between models.

\section{Study Variables Recorded}

The data set was prepared using treatment means from these studies, which are summarized in Table 1. One study (Samuelson et al., 2001) was counted as 2 studies because they reported on 2 studies performed at different times with different animals. Berthiaume et al. (2006) and Davidson et al. (2008) reported observations for primiparous and multiparous cows separately. As other authors reported their findings as effects on multiparous or mixed parity cows, the least squares means of these studies were averaged, and the results presented as one observation per study on mixed parities. One study (Chilliard and Doreau, 1997) did not report body weight, so the AC default value of $612 \mathrm{~kg}$ for mixed-parity Holstein cows was used. Overton et al. (1996), Overton et al. (1998), and Benefield et al.
(2009) presented results from 2 separate period lengths. For these studies, only a single comparison was made for the longest observational period because the diets did not change. Some studies tested multiple levels of RPM against a single control diet (Pappas et al., 1984a,b; Pisulewski and Kowalski, 1999a; Soder and Holden, 1999; Samuelson et al., 2001, study 1; Berthiaume et al., 2006; Lara et al., 2006; Benefield et al., 2009) and were counted as $4,4,4,2,3,2,3$, and 2 comparisons, respectively. In all studies, it was assumed that milk protein was reported as milk CP unless it was expressly noted as true milk protein (TMP). Milk CP was converted to TMP by multiplying milk CP by 0.94 .

Data entered into a relational database included the reported treatment means for DMI, milk production, milk fat percentage, and TMP percentage, as well as for milk fat and milk protein yields and their standard errors of the mean (SEM). When yields of milk fat and milk protein were not reported, they were calculated by multiplying milk production by the percentage of TMP or milk fat. When SEM was not reported, it was estimated from other measures of variance. A database was constructed with the reported mean DMI, milk production, TMP percentage, and milk fat percentage. Additionally, all factors that were thought to have a possibility of affecting the response to RPM were recorded. These factors included the number of AA predicted to be deficient but not the severity of that deficiency by the $\mathrm{AC}$ model using the following scale: $0=$ no predicted AA deficiency; 1 = predicted Met deficiency only; $2=$ predicted Met and Lys deficiency; $3=$ predicted deficiency of Met and Lys plus at least one other AA. Also recorded according to the AC model was the estimated amount of MP that flowed to the intestine (g/d) as well as the predicted MP balance, Met and Lys flow (g/d), Met and Lys deficiency, Met and Lys percentage of MP, and change in grams of Met flow. Energy balance as computed by NRC was recorded, as was dietary NDF, NFC CP, and ether extract (all as \% of DM) as well as forage:concentrate ratio. The days on which animals were fed treatment diets, daily intake of RPM, DIM, BW, and breed of cattle were similarly recorded. Breed effects were evaluated as Holstein versus other breeds. One study (Younge et al., 2001) did not report a breed, and breed data from this study were included as non-Holstein. The effects of different types of rations based on their forage source having an effect on RPM response was investigated using the following ration grouping: 1) alfalfa-based for diets in which greater than $40 \%$ of the forage was from alfalfa either as hay or silage; 2) corn silage-based for diets in which at least $90 \%$ of the forage was corn silage; 3 ) grass-based when grass as hay, silage, or green feed made up more than $90 \%$ of the forage; and 4) grass-corn silage-based when 
Table 1. Descriptions of studies used for meta-analysis

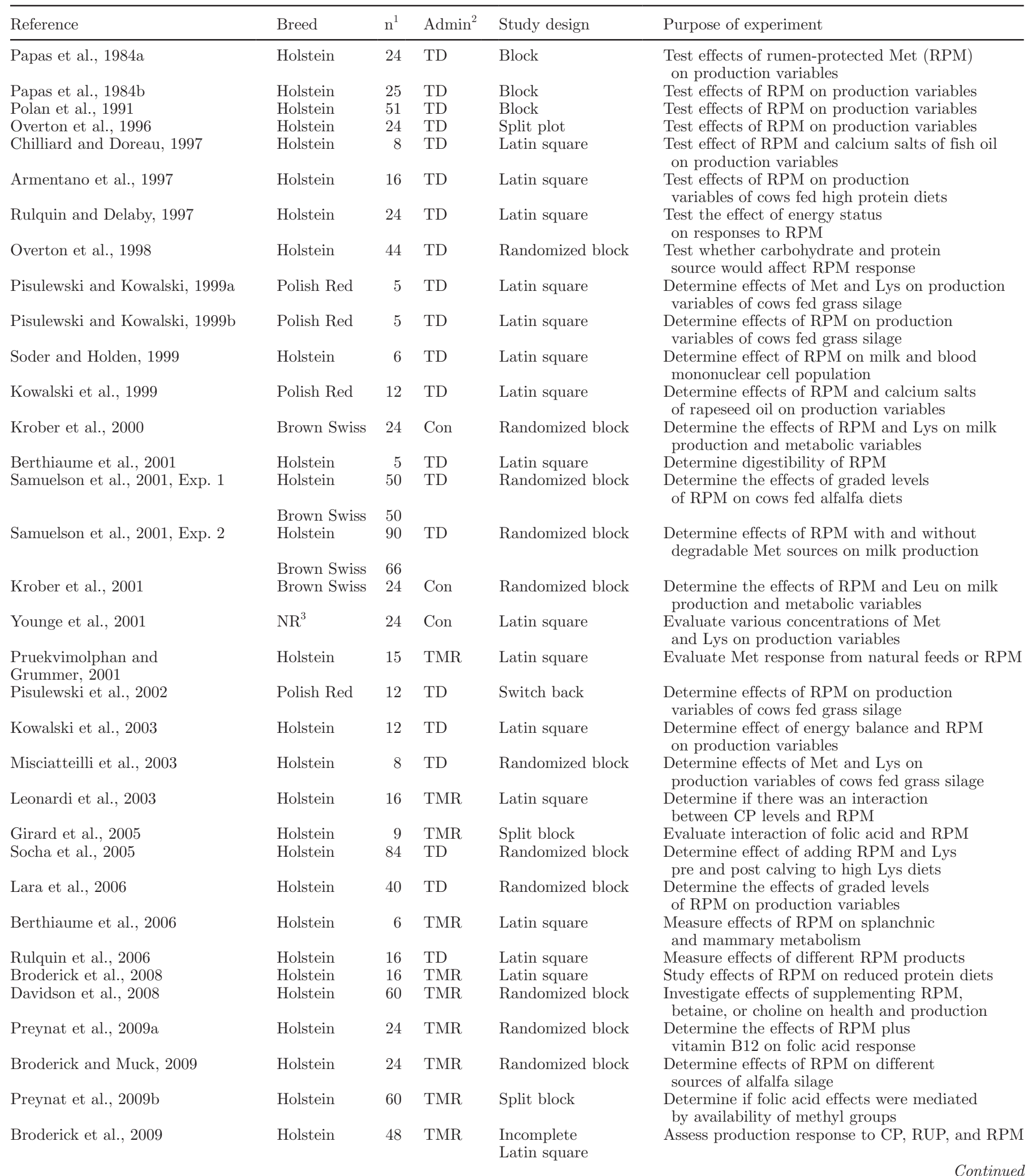


Table 1 (Continued). Descriptions of studies used for meta-analysis

\begin{tabular}{llllll}
\hline Reference & Breed & $\mathrm{n}^{1}$ & $\operatorname{Admin}^{2}$ & Study design & Purpose of experiment \\
\hline Benefield et al., 2009 & Holstein & 16 & TMR & Latin square & $\begin{array}{c}\text { Determine effect of RPM products and } \\
\text { period length on production responses } \\
\text { Ordway et al., 2009 }\end{array}$ \\
\hline
\end{tabular}

${ }^{1}$ Number of animals fed RPM.

${ }^{2}$ Method of feeding: $\mathrm{Con}=$ mixed in concentrate; $\mathrm{TD}=$ topdressed; $\mathrm{TMR}=$ mixed in total ration.

${ }^{3} \mathrm{NR}=$ not reported.

all the forage was a mixture of grass plus corn silage and grass as grass hay or grass silage.

To define potential availability and efficiency differences between RPM sources, 3 synthesized variables were constructed on the reported mean responses. A calculation of the percent use of DL-Met was performed assuming that Mepron contained $85 \%$ and Smartamine contained $75 \%$ DL-Met and that $9.5 \%$ of the milk protein increase, equivalent to Cys plus Met in milk, was of RPM origin (Rostock Feed Evaluation System; Beyer et al., 2003). There was also a calculation of product efficiency, defined as change in grams of TMP per gram of RPM fed. Milk nitrogen efficiency, defined as grams of $\mathrm{N}$ isolated in TMP divided by grams of $\mathrm{N}$ consumed, was also calculated. Formulas used were

$$
\begin{aligned}
& \text { N consumed }(\mathrm{g})=(\mathrm{DMI} \times \mathrm{CP} \% / 100) / 6.25 \\
& \mathrm{~N} \text { in milk }(\mathrm{g})=\text { milk protein yield } / 6.38 ; \\
& \text { DL-Met use }=[(\text { change in TMP }(\mathrm{g}) \times 0.095) / \\
& (\text { product amount }(\mathrm{g}) \times \text { DL-Met } \%)] \times 100 ; \\
& \text { Product efficiency }=\text { change in TMP }(\mathrm{g}) / \\
& \text { amount of RPM fed }(\mathrm{g}) ; \\
& \text { Milk nitrogen efficiency }=\mathrm{g} \text { of } \mathrm{N} \text { in milk/ } \\
& \mathrm{g} \text { of } \mathrm{N} \text { consumed } \times 100 .
\end{aligned}
$$

\section{Statistical Analysis}

Meta-analysis was conducted on the outcome (i.e., control-RPM treatment) for DMI, milk yield, milk fat percentage and yield, as well as TMP percentage and yield using methods described by Arthur et al. (2001). Study was treated as a random effect, and all outcomes were weighted by the inverse of the squared standard error of the mean (St-Pierre, 2001). This method allowed calculation of the effect size of the outcome, the variance of the weighted mean, and the $95 \%$ CI. In this instance, the $95 \%$ CI returns the range of the value for the next sample taken from the population. A Q statistic for heterogeneity was also calculated for these variables (Lean et al., 2009). When heterogeneity was deemed significant by the chi-square test, a meta-regression analysis was conducted using the effect size of each trial as the outcome. Coded amount of AA deficiency and product were fixed variables; the others, such as RPM dose, ration nutrient content, DIM, days on study, and grams of Met deficiency, were continuous variables. Variables were first identified individually when they were significant at $P<0.20$. Then, all such identified variables were evaluated by stepwise elimination until all variables in the model were significant at $P \leq 0.10$.

Statistical analysis of AA differences between models and of the synthesized variables was by Proc Mixed of SAS (version 9.0; SAS Institute Inc., Cary, NC). The model included the effects of model for comparisons of model effects and the effects of RPM source for the synthetic variables with study as a random factor (StPierre, 2001). The model contained the effects of amount of RPM as a covariate. However, the effects of RPM amounts were not significant and so were dropped.

\section{RESULTS}

In all, 75 diet comparisons from 36 studies were evaluated with 17 studies evaluating Mepron and 18 evaluating Smartamine. One study (Benefield et al., 2009) evaluated both products. Twenty-eight diets had a forage base of alfalfa or alfalfa corn silage (477 cows), whereas 12 diets were corn silage-based (186 cows), 13 diets were grass-based (129 cows), and 22 were grasscorn silage diets (248 cows). The majority of studies were conducted on Holsteins (697 cows); non-Holsteins were Brown Swiss, Red Polish, and mixed-breed cattle (343 cows). A list of mean characteristics for Mepron and Smartamine experiments as predicted by the AC model is presented in Table 2. In most cases, Mepron studies exhibited greater range from minimum to maximum. For length of study, DIM, CP percentage, and Met deficiency, Mepron studies had the lowest minimum value, whereas Smartamine studies displayed the highest maximum. For the ration variables NDF percent- 
Table 2. Least squares means, standard errors, minima, and maxima for differences between control rations used in meta-analysis of rumen-protected Met (RPM) products as predicted by the AminoCow model (http:// www.makemilknotmanure.com/aminocow.php)

\begin{tabular}{|c|c|c|c|c|c|c|}
\hline \multirow[b]{2}{*}{ Item } & \multicolumn{2}{|c|}{ Product $^{1}$} & \multirow[b]{2}{*}{$\mathrm{SE}$} & \multirow[b]{2}{*}{$P<$} & \multirow[b]{2}{*}{ Minimum } & \multirow[b]{2}{*}{ Maximum } \\
\hline & $\begin{array}{c}\mathrm{M} \\
(\mathrm{n}=18)\end{array}$ & $\begin{array}{c}\mathrm{S} \\
(\mathrm{n}=18)\end{array}$ & & & & \\
\hline \multicolumn{7}{|l|}{ Cow variable } \\
\hline AA deficiency code & 1.46 & 1.70 & 0.26 & 0.49 & 0 & 3 \\
\hline Length of period (d) & 53.2 & 53.0 & 10.3 & 0.95 & 14 & 305 \\
\hline Average DIM (d) & 106.4 & 102.3 & 7.1 & 0.55 & 35 & 180 \\
\hline BW (kg) & 615.2 & 607.5 & 6.6 & 0.33 & 546 & 700 \\
\hline Amount of RPM fed $(\mathrm{g} / \mathrm{d})$ & 21.2 & 16.7 & 2.3 & 0.17 & 5 & 72 \\
\hline \multicolumn{7}{|l|}{ Production variable } \\
\hline $\mathrm{DMI}(\mathrm{kg} / \mathrm{d})$ & 21.2 & 20.6 & 0.7 & 0.32 & 13.9 & 28.7 \\
\hline Milk production $(\mathrm{kg} / \mathrm{d})$ & 34.0 & 32.6 & 1.4 & 0.30 & 17.2 & 46.3 \\
\hline True milk protein (\%) & 2.92 & 2.89 & 0.04 & 0.56 & 2.38 & 3.22 \\
\hline Milk fat $(\%)$ & 3.52 & 3.60 & 0.10 & 0.49 & 2.27 & 4.88 \\
\hline \multicolumn{7}{|l|}{ Ration variable } \\
\hline Energy balance (Mcal/d) & 1.10 & 0.57 & 0.75 & 0.59 & -6.0 & 9.6 \\
\hline $\mathrm{CP}(\%$ of $\mathrm{DM})$ & 17.0 & 16.8 & 0.3 & 0.75 & 14.0 & 20.0 \\
\hline NDF ( $\%$ of DM) & 32.7 & 33.6 & 1.2 & 0.41 & 24.2 & 51.2 \\
\hline NFC ( $\%$ of DM) & 38.5 & 37.4 & 1.4 & 0.44 & 18.6 & 51.5 \\
\hline Ether extract (\% of DM) & 4.20 & 4.30 & 0.25 & 0.76 & 2.04 & 6.99 \\
\hline \multicolumn{7}{|l|}{ Model-dependent variables } \\
\hline $\operatorname{MP}(\mathrm{g} / \mathrm{d})$ & 2,263 & 2,093 & 89 & 0.10 & 1,329 & 3,123 \\
\hline Met deficiency $(\mathrm{g} / \mathrm{d})$ & -3.6 & -3.4 & 1.4 & 0.91 & -18 & 14 \\
\hline Met $(\%$ of MP) & 1.88 & 1.88 & 0.02 & 0.92 & 1.70 & 2.16 \\
\hline Lys deficiency $(\mathrm{g} / \mathrm{d})$ & 8.0 & 3.9 & 4.9 & 0.43 & -45 & 59 \\
\hline Lys $(\%$ of MP) & 6.60 & 6.56 & 0.09 & 0.64 & 3.88 & 7.14 \\
\hline
\end{tabular}

${ }^{1} \mathrm{M}=$ Mepron (Evonik Industries, Hanau, Germany); $\mathrm{S}=$ Smartamine (Adisseo, Antony, France).

age, NFC percentage, and ether extract percentage as well as Met and Lys as percentage of MP, Smartamine studies exhibited the smallest and greatest values. For all variables, with the exception of a trend for predicted MP flow, there was no difference detected in control groups in terms of cows or dietary nutrients for Smartamine or Mepron experiments. It is thus concluded that these diets are not different, and the experiments may be interpreted as being from similar cow populations.

\section{Model Effects}

The NRC and AC model predictions for Met, Lys and MP flows are presented in Table 3. There were no differences in predictions of grams of metabolizable Met, Met as percentage of MP, or grams of Lys flow between the NRC (2001) model and the AC model. For this data set, AC predicted lower MP flow (mean difference of $31.9 \mathrm{~g} ; P<0.03)$ than did the NRC model as well as higher Lys as percentage of MP $(0.15 \% ; P<$ $0.0001)$. The largest difference was for the prediction of MP balance, which was 495 g greater for the AC model than for the NRC model. Regression equations to calculate NRC values from AC predictions are presented in Table 4, and except for MP balance, displayed a high correlation between model predictions.

\section{Meta-Analyses}

Meta-analysis of production responses to RPM feeding is presented in Table 5 . Overall, this analysis shows a slight decrease in DMI and a slight increase in

Table 3. Least squares means for prediction of MP and AA flows between AminoCow (AC; http://www. makemilknotmanure.com/aminocow.php) and NRC (2001) models for all evaluated rations ( $\mathrm{n}=136)$

\begin{tabular}{lcccc}
\hline & \multicolumn{2}{c}{ Model } & & \\
\cline { 2 - 3 } Prediction & AC & NRC & SE & $P<$ \\
\hline MP (g/d) & $2,178.4$ & $2,210.3$ & 72.8 & 0.03 \\
MP balance (g/d) & 495.0 & 9.2 & 37.7 & $<0.001$ \\
Met (g/d) & 50.6 & 49.4 & 1.48 & 0.23 \\
Met (\% of MP) & 2.20 & 2.13 & 0.05 & 0.13 \\
Lys (g/d) & 152.0 & 150.0 & 5.35 & 0.20 \\
Lys (\% of MP) & 6.56 & 6.41 & 0.08 & $<0.001$ \\
\hline
\end{tabular}


Table 4. Regression equations to predict NRC (2001) protein and AA flows from AminoCow (AC; http:// www.makemilknotmanure.com/aminocow.php) values

\begin{tabular}{lc}
\hline Equation $^{1}$ & $\mathrm{R}^{2}=$ \\
\hline $\mathrm{MP}_{\mathrm{NRC}}(\mathrm{g} / \mathrm{d})=180.30( \pm 73.94)+0.93( \pm 0.03) \times \mathrm{MP}_{\mathrm{AC}}$ & 0.92 \\
MP balance $_{\mathrm{NRC}}(\mathrm{g} / \mathrm{d})=-229.21( \pm 26.90)+0.48( \pm 0.05) \times \mathrm{MP}_{\text {balanceAC }}$ & 0.44 \\
Met flow & 0.92 \\
Met $\% \mathrm{MP}_{\mathrm{NRC}}=0.20( \pm 0.05)+0.88( \pm 0.02) \times$ Met $\% \mathrm{MP}_{\mathrm{AC}}$ & 0.92 \\
Lys flow & 0.79 \\
Lys $_{\mathrm{NRC}}(\mathrm{g} / \mathrm{d})=23.09( \pm 5.89)+0.83( \pm 0.04) \times \mathrm{Lys}_{\mathrm{NRC}}=1.68( \pm 0.21)+0.72( \pm 0.03) \times$ Lys $\% \mathrm{MP}_{\mathrm{AC}}$ & 0.80 \\
\hline
\end{tabular}

${ }^{1} \mathrm{MP}_{\mathrm{NRC}}(\mathrm{g} / \mathrm{d})=\mathrm{g} / \mathrm{d}$ of MP predicted by the NRC model; $\mathrm{MP}_{\mathrm{AC}}(\mathrm{g} / \mathrm{d})=\mathrm{g} / \mathrm{d}$ of $\mathrm{MP}$ predicted by the AC model. MP balance NRC $(\mathrm{g} / \mathrm{d})=$ the difference between requirement and supply as predicted by the NRC model; $\mathrm{MPbalance}_{\mathrm{AC}}=$ the difference between requirement and supply as predicted by the AC model. Met flow ${ }_{\mathrm{NRC}}$ $(\mathrm{g} / \mathrm{d})=\mathrm{g} / \mathrm{d}$ of Met flowing to the small intestine as predicted by the NRC model; Met flow $\mathrm{AC}(\mathrm{g} / \mathrm{d})=\mathrm{g} / \mathrm{d}$ of Met flowing to the small intestine as predicted by the $\mathrm{AC}$ model. Met $\% \mathrm{MP}_{\mathrm{NRC}}=$ Met as $\%$ of MP predicted by the NRC model; Met $\% \mathrm{MP}_{\mathrm{AC}}=$ Met as $\%$ of MP as predicted by the AC model. Lys flow ${ }_{\mathrm{NRC}}(\mathrm{g} / \mathrm{d})=\mathrm{g} / \mathrm{d}$ of Lys flowing to the small intestine as predicted by the NRC model; Lys flow ${ }_{A C}(g / d)=g / d$ of Lys flowing to the small intestine as predicted by the $\mathrm{AC}$ model. Lys $\% \mathrm{MP}_{\mathrm{NRC}}=$ Lys as $\%$ of MP predicted by the NRC model; Lys $\% \mathrm{MP}_{\mathrm{AC}}=$ Lys as \% of MP as predicted by the AC model.

milk production, with a $0.07 \%$ increase in TMP that resulted in $27 \mathrm{~g}$ greater production of TMP. When feeding RPM, milk fat percentage was marginally decreased $(-0.01 \%)$, but increased milk production resulted in $11 \mathrm{~g}$ more milk fat production. With the exception of the change in milk production, the exactness of the upper and lower CI indicates high confidence that further experimentation would yield the same result. Milk production was the only variable to exhibit heterogeneity, suggesting that other factors may be operating. The resultant meta-regression analysis for change in milk production is presented in Table 6 .

The meta-analysis for the size effect of deficiency code on response to RPM is presented in Table 7. There is evidence that other factors are operating for change in DMI for cows deficient in multiple AA. Likewise, change in milk production in response to RPM displayed highly significant heterogeneity for cows that were not predicted to be deficient in AA, those predicted to be deficient in Met, and those deficient in several AA, but not for those predicted to be deficient in Met and Lys. The multiple regression equations for change in milk for code 0 and 1 cows only are presented, as there were no significant correlations for those of code 3. There was no significant heterogeneity for code 2. Another moderating variable of interest was the effect of breed, Holstein or non-Holstein (Table 8), because Holsteins produced less milk when RPM was fed $(-0.25 \mathrm{~kg} / \mathrm{d})$, whereas non-Holsteins produced more milk $(0.27 \mathrm{~kg} / \mathrm{d})$. Dry matter intake for non-Holsteins and milk production for both breeds indicated that complicating factors were operating. The multivariate regressions for these effects are also presented in Table 6 . Effect size of dietary forage when cows are fed RPM is presented in Table 9 . The analysis revealed that cows fed alfalfa-based diets responded with more milk $(0.383 \mathrm{~kg} / \mathrm{d})$, whereas those fed other forages decreased milk production. The effect of increased milk production was detected for both RPM products $(0.425 \mathrm{~kg} / \mathrm{d}$ for Mepron and $0.143 \mathrm{~kg} / \mathrm{d}$ for Smartamine). For all other forages, milk production declined for both products (data not shown). Heterogeneity was again detected in milk production for both alfalfa and grass-corn silage based diets. The regression for milk change after feeding RPM for grass-corn silage fed cows is presented in Table 6 . There were no significant terms for milk change in the alfalfa diet due to feeding RPM.

Meta-analysis of product effects of changes in production variables is presented in Table 10. Milk fat percentage and TMP percentage increases for indi-

Table 5. Meta-analysis of effect size of rumen-protected methionine addition to rations of lactating cows

\begin{tabular}{|c|c|c|c|c|c|c|c|c|}
\hline Response $^{1}$ & $\begin{array}{l}\text { Adjusted } \\
\text { mean effect }\end{array}$ & Variance & Minimum & Maximum & $\begin{array}{l}\text { Lower } \\
95 \% \text { CI }\end{array}$ & $\begin{array}{l}\text { Upper } \\
95 \% \text { CI }\end{array}$ & $\mathrm{Q}^{2}$ & $\begin{array}{c}\text { Heterogeneity } \\
\text { probability }\end{array}$ \\
\hline DMI (kg) & -0.04 & 0.27 & -2.10 & 1.50 & -0.04 & -0.04 & 58.79 & NS \\
\hline Milk (kg) & 0.02 & 0.78 & -4.20 & 4.40 & -1.19 & 1.23 & 170.72 & $<0.001$ \\
\hline True milk protein yield (kg) & 0.027 & 0.001 & -0.073 & 0.186 & 0.025 & 0.025 & 0.22 & NS \\
\hline Milk fat (\%) & -0.01 & 0.012 & -0.30 & 0.41 & -0.01 & -0.01 & 2.53 & NS \\
\hline Milk fat yield (kg) & 0.011 & 0.003 & -0.194 & 0.193 & 0.010 & 0.010 & 0.59 & NS \\
\hline
\end{tabular}

${ }^{1}$ Responses measured on 75 comparisons of 1,040 cows.

${ }^{2} \mathrm{Q}=$ chi-squared value for homogeneity. 
Table 6. Significant equations for multiple regression responses of size effects due to dietary supplementation of rumen-protected methionine $(\mathrm{RPM})$

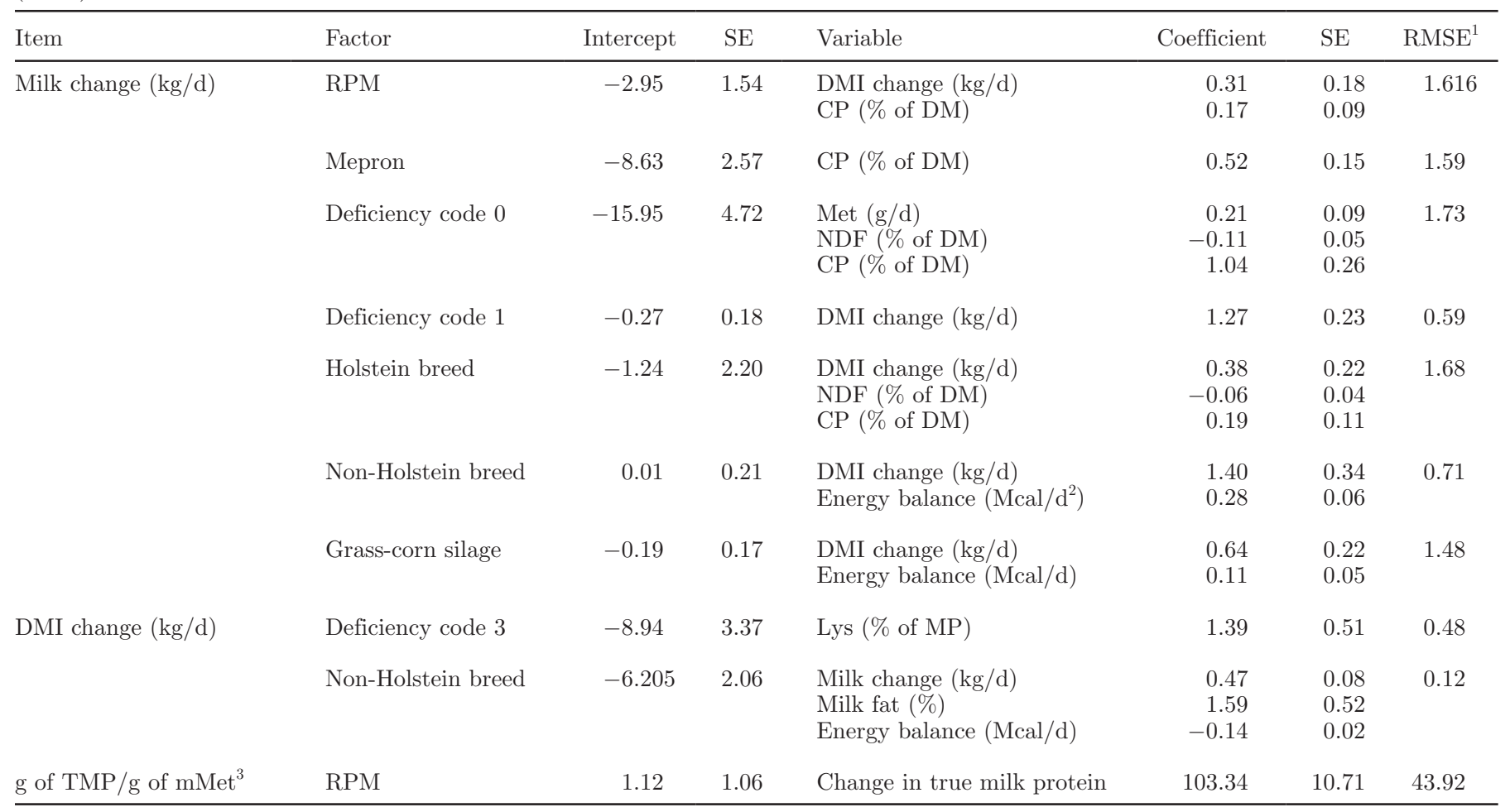

${ }^{1}$ Root mean square error.

${ }^{2} \mathrm{Mcal} / \mathrm{d}=$ megacalories of $\mathrm{NE}_{\mathrm{L}}$ per day.

${ }^{3} \mathrm{~g}$ of $\mathrm{TMP} / \mathrm{g}$ of $\mathrm{mMet}=\mathrm{g}$ of true milk protein per $\mathrm{g}$ of metabolizable methionine.

vidual products are similar to those observed for both combined. For this study, the previously reported mean effect of RPM feeding of decreased feed intake and increased milk production was due to Mepron. The greater milk production resulted in twice as much milk protein for Mepron as for Smartamine (37 g vs. $16 \mathrm{~g}$ ). Milk fat yield was increased for Mepron-supplemented cows, but milk fat changes were almost nonexistent for Smartamine-supplemented cows. Further, the heterogeneity for change in milk production due to feeding RPM is largely attributable to Mepron. This regression equation is also presented in Table 6 .

\section{DISCUSSION}

The AC model was selected because of the author's familiarity with the program and because it provides gram requirements of Met and Lys based on a factorial system as well as predictions of duodenal flows of individual AA flow and $\mathrm{AA}$ as percentage of MP. It was expected that this would provide an insight into whether relationships between Met and Lys should better be described as weights or percentages. However, because the NRC (2001) model is considered the stan- dard for predicting AA flow, diets were also entered into that model to provide a comparison of predicted Met and Lys flows and Met and Lys as percentage of $\mathrm{MP}$ relative to $\mathrm{AC}$ to acknowledge any bias between the models. Although there are significant differences, the closeness of predictions given the errors in experimental measurement for Met and Lys, as well as the high $\mathrm{R}^{2}$ for all regression equations except MP balance, indicates that both programs are attempting to model the same biology. Therefore, it was concluded that the results of this study using only the AC model could be interpreted without bias and that inclusion or exclusion of Met and Lys flow data in subsequent regression equations was not due to model predictions. The large difference between the models was in prediction of the MP balance. Of the 135 diets compared for MP balance, 66 of them were in negative MP balance according to the NRC model (mean MP balance was $-155 \mathrm{~g}$ ), whereas only 4 predictions were negative in AC (mean $-28 \mathrm{~g}$ ). Metabolizable protein deficiencies of the magnitude predicted by the NRC model would be expected to decrease production responses, but this was not observed. It may have been that cows lost body protein to maintain milk production during the length 
Table 7. Meta-analysis of effect size for lactating cows predicted to have varying levels of AA deficiency when rumen-protected methionine (RPM) is added to diets

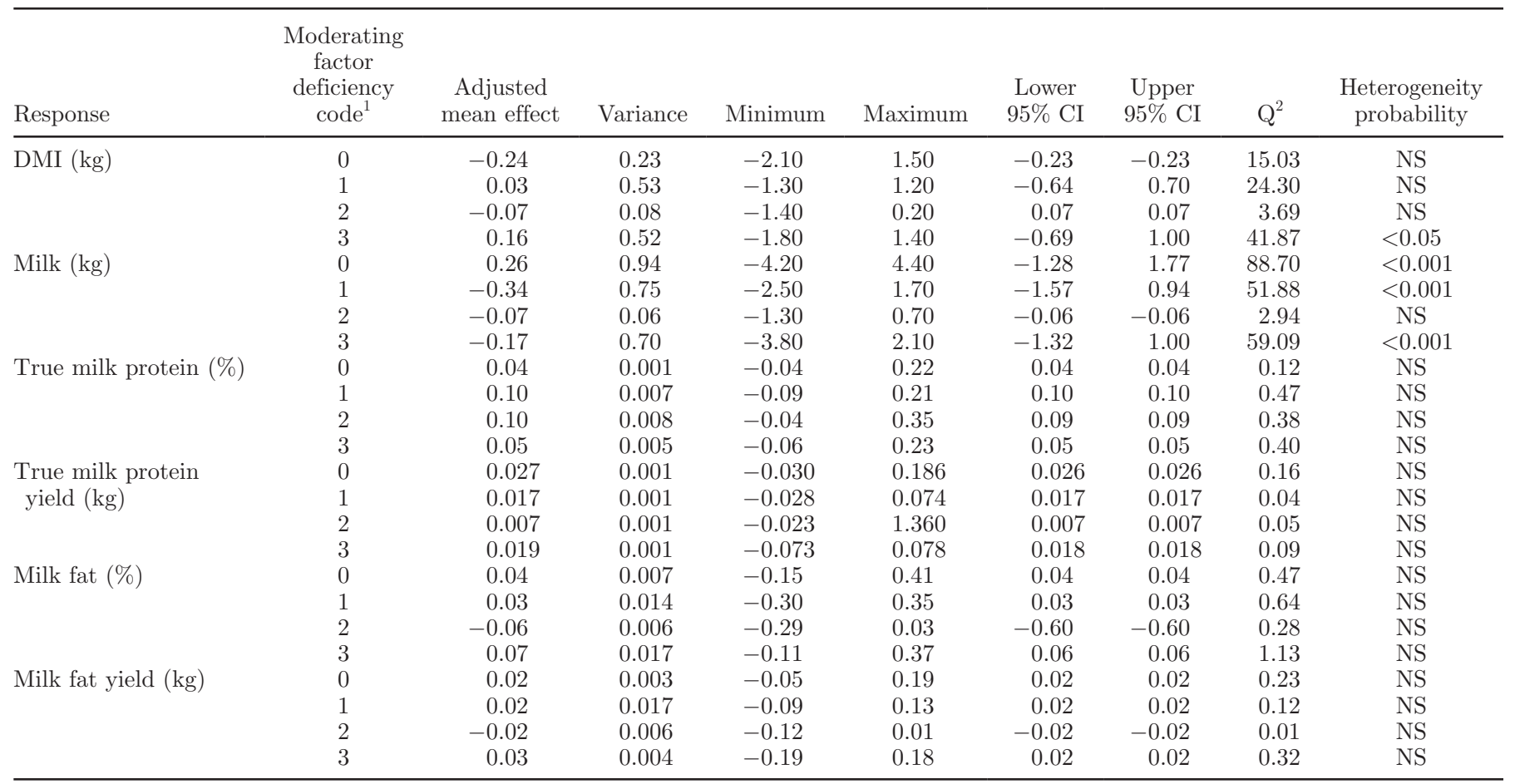

${ }^{1} \mathrm{AA}$ deficiency code $=0$ for no predicted AA deficiency, 1 for predicted Met deficiency, 2 for predicted Met + Lys deficiency, and 3 for predicted Met + Lys +1 other AA deficiency. There were 22 comparisons with 307 treated cows for AA code 0,18 comparisons and 224 cows for code 1 , 11 comparisons and 216 cows for code 2 , and 26 comparisons with 395 cows for code 3.

${ }^{2} \mathrm{Q}=$ chi-squared value for homogeneity.

of these studies. However, protein and AA losses of this magnitude would equate to a weight loss of about 450 $\mathrm{g}$ per day, which for an average of $53 \mathrm{~d}$ on study would have resulted in a total weight loss of $23 \mathrm{~kg}$ per cow. Body weight losses of this magnitude would likely have been reported, which they were not. In fact, those studies reporting body weight or body condition changes generally reported increases as lactation progressed, as is normally observed.

Although it is not possible to detect the true MP requirements in these studies, it does seem logical that the MP requirement may be between the predictions of these 2 models. Given this data, it would be impossible to significantly lower dietary $\mathrm{CP}$ through AA

Table 8. Meta-analysis of effect size of Holstein and non-Holstein breeds of lactating cows when rumen-protected methionine is added to diets

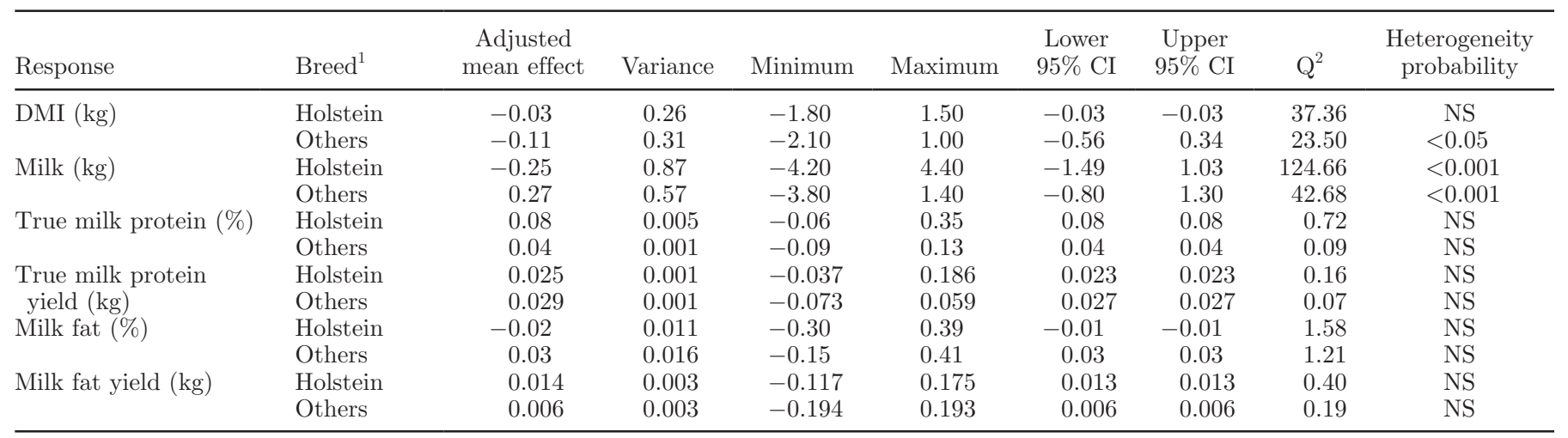

${ }^{1}$ Holstein breed: 56 comparisons, 697 cows; combined other breeds: 19 comparisons, 343 cows.

${ }^{2} \mathrm{Q}=$ chi-squared value for homogeneity. 
Table 9. Meta-analysis of effect size of main forage source on production variables for cows fed rumen-protected methionine (RPM)

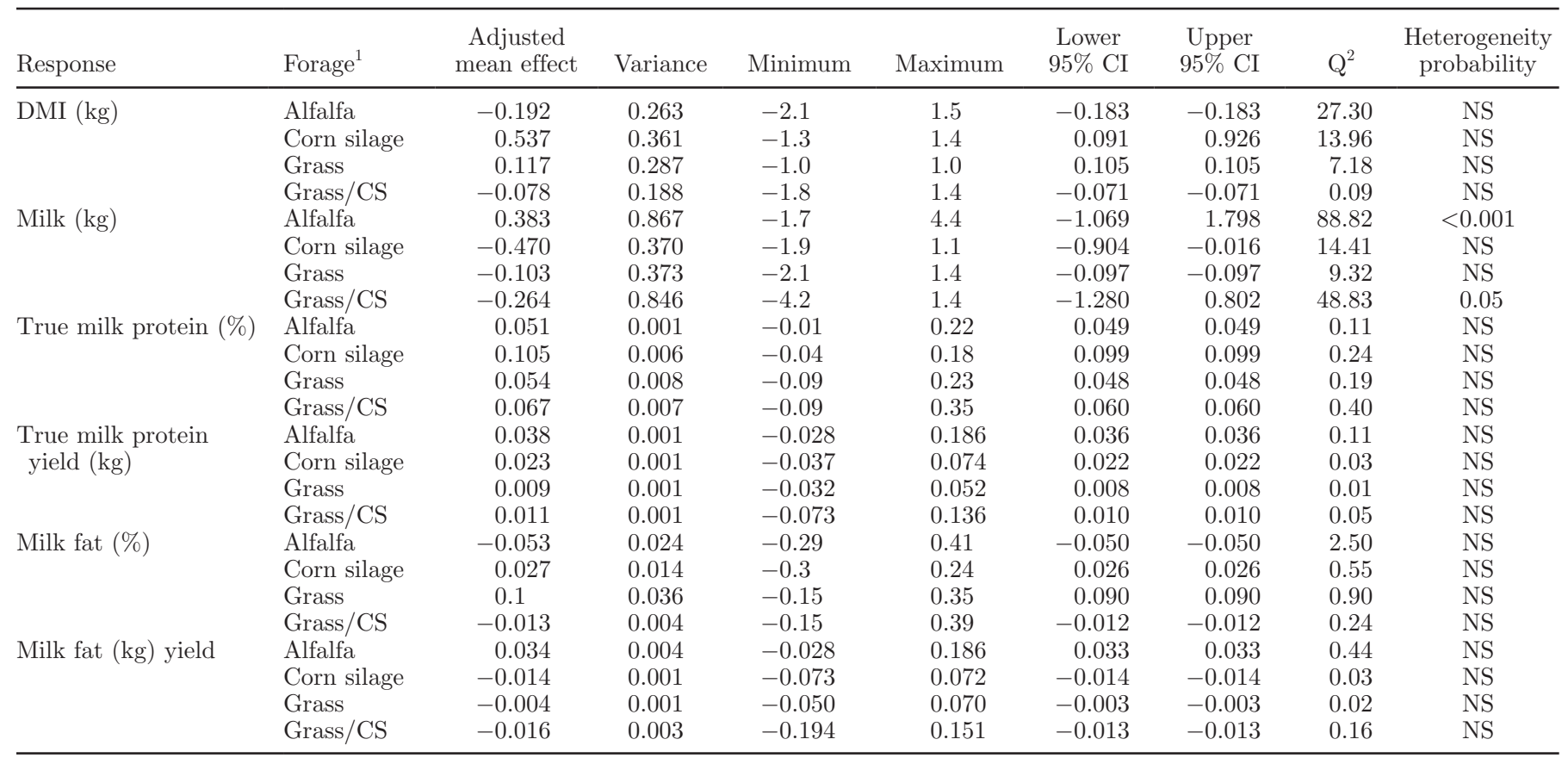

${ }^{1}$ Alfalfa $=$ diets of alfalfa (silage and/or hay) or alfalfa plus corn silage, where alfalfa provided more than $40 \%$ of forage base; 28 diet comparisons with 477 cows; Corn silage = diets where corn silage made up all or $90 \%$ of forage base; 12 diet comparisons of 186 cows; Grass = diets where grass silage and/or hay made up more than $90 \%$ of forage base; 13 diet comparisons of 129 cows; Grass/CS = diets of grass (hay or silage) and corn silage but where greater than $30 \%$ of forage base was grass; 29 diet comparisons of 297 cows.

${ }^{2} \mathrm{Q}=$ chi-squared value for homogeneity.

balance if the NRC MP requirement is to be fulfilled. However, studies have already indicated that it is possible to lower dietary $\mathrm{CP}$ and reduce loss of nitrogen in urine without sacrificing milk production (Leonardi et al., 2003; Broderick et al., 2008, 2009b). Determining the true MP requirements at various production levels would seem to be a priority if dairy farmers are to lower nitrogen spillage into the environment without loss of milk production.
A priori, it was thought that predicted deficiencies of Met, measured as grams or as percentage of MP, would show a strong relationship to TMP percentage and yield when RPM was fed. It was further supposed that a similar situation existed for Lys (NRC, 2001). If $\mathrm{AC}$ and $\mathrm{NRC}$ models exhibit divergent predictions, misinterpretation of the influence of Met and Lys in response to RPM may occur. The fact that no effect of Met or Lys could be detected on TMP or milk yield and

Table 10. Meta-analysis of effect size of production responses when Mepron (Evonik Industries, Hanau, Germany) or Smartamine (Adisseo, Antony, France) is included in diets of lactating cows

\begin{tabular}{|c|c|c|c|c|c|c|c|c|c|}
\hline Response & Product $^{1}$ & $\begin{array}{l}\text { Adjusted } \\
\text { mean effect }\end{array}$ & Variance & Minimum & Maximum & $\begin{array}{l}\text { Lower } \\
95 \% \mathrm{CI}\end{array}$ & $\begin{array}{l}\text { Upper } \\
95 \% \mathrm{CI}\end{array}$ & $\mathrm{Q}^{2}$ & $\begin{array}{c}\text { Heterogeneity } \\
\text { probability }\end{array}$ \\
\hline \multirow[t]{2}{*}{ DMI (kg) } & $\mathrm{M}$ & -0.10 & 0.18 & -2.10 & 1.20 & -0.09 & -0.09 & 22.98 & NS \\
\hline & $\mathrm{S}$ & 0.04 & 0.39 & -1.80 & 1.50 & 0.04 & 0.04 & 36.59 & NS \\
\hline \multirow[t]{2}{*}{ Milk (kg) } & M & 0.35 & 0.99 & -3.80 & 4.40 & -1.21 & 1.87 & 123.09 & $<0.001$ \\
\hline & $\mathrm{S}$ & -0.22 & 0.47 & -4.20 & 1.70 & -0.66 & 0.24 & 43.73 & NS \\
\hline \multirow[t]{2}{*}{ True milk protein $(\%)$} & $\mathrm{M}$ & 0.06 & 0.002 & -0.02 & 0.35 & 0.05 & 0.05 & 0.26 & $\mathrm{NS}$ \\
\hline & $\mathrm{S}$ & 0.08 & 0.006 & -0.09 & 0.23 & 0.07 & 0.07 & 0.59 & NS \\
\hline \multirow{2}{*}{$\begin{array}{l}\text { True milk protein } \\
\text { yield }(\mathrm{kg})\end{array}$} & $\mathrm{M}$ & 0.037 & 0.001 & -0.073 & 0.186 & 0.035 & 0.035 & 0.15 & $\mathrm{NS}$ \\
\hline & $\mathrm{S}$ & 0.016 & 0.001 & 0.037 & 0.075 & 0.015 & 0.015 & 0.05 & NS \\
\hline \multirow[t]{2}{*}{ Milk fat (\%) } & M & -0.01 & 0.004 & -0.30 & 0.41 & -0.01 & -0.01 & 3.62 & NS \\
\hline & $\mathrm{S}$ & -0.02 & 0.040 & -0.29 & 0.39 & -0.02 & -0.02 & 3.75 & $\mathrm{NS}$ \\
\hline \multirow[t]{2}{*}{ Milk fat yield (kg) } & M & 0.024 & 0.004 & -0.19 & 0.193 & 0.023 & 0.023 & 0.11 & NS \\
\hline & $\mathrm{S}$ & -0.002 & 0.001 & -0.117 & 0.151 & -0.002 & -0.002 & 0.11 & NS \\
\hline
\end{tabular}

${ }^{1} \mathrm{M}=$ Mepron; 37 comparisons on 583 cows; $\mathrm{S}=$ Smartamine; 38 comparisons on 457 cows.

${ }^{2} \mathrm{Q}=$ chi-squared value for homogeneity. 
only limited effects on DMI (Table 6) made it all the more important that model biases did not contribute to this finding. Significant differences in treatment means and models should be kept in mind when interpreting the results presented in this study.

The largest effect of adding RPM to the diet of lactating dairy cows was a $0.07 \%$ increase in TMP percentage with a resultant $27 \mathrm{~g}$ increase of TMP yield. Effects on DMI, milk production, and milk fat were minor. Thus, based on this analysis, farmers and nutritionists can have confidence that adding RPM to rations will result in a higher percentage of TMP and greater yield of milk protein. It is of more interest that this response did not depend on the amount of RPM fed, the severity of the Met deficiency, or the amount of dietary Lys (either as $\mathrm{g} / \mathrm{d}$ or as \% of MP). Rather, the mere addition of RPM appeared to have stimulated increased TMP percentage. This seems to be illogical and may be because of the inefficiency of Met utilization as supply increases (Doepel et al., 2004) or other nutrients could become limiting at the mammary gland to prevent greater protein synthesis (Cant et al., 2009). The mean weighted increase in TMP per gram of metabolizable Met increase was 7.5 , a value in the mid range as reported by Vyas and Erdman (2009), who studied dietary increases in both Met and Lys. All complicating factors in response to feeding RPM appear to be in regard to the effect size of the milk yield. When feeding RPM, it appears that cows with energy in excess and that consume more DM have a greater milk yield response, as might be expected. This is slightly contrary to the study by Rulquin and Delaby (1997), which reported that TMP increased in response to RPM when energy balance was more positive, but milk output did not. In this meta-analysis, the TMP response to RPM was not affected by energy, but the change in milk yield associated with RPM feeding was affected. In fact, for all diets in this study, there was a negative correlation between cows in greater energy balance and change in TMP percentage $\left(\mathrm{R}^{2}=-0.35, P<0.001\right)$.

In this study, there was no correlation of Lys as grams or as percentage of MP to TMP percentage $\left(\mathrm{R}^{2}<0.07\right)$, and there was no indication of Lys as a complicating factor to RPM response. This may be because there was essentially no change in Lys supply that accompanied the increase in Met in these studies. However, higher predicted flows of Lys did not result in greater TMP responses to RPM. This suggests that there may be other factors that were not uncovered in the meta-analysis, and that these predisposing factors need to be elucidated before the exact role of RPM in milk production and milk protein synthesis can be established. When comparing responses in TMP yield to RPM feeding, in studies where milk production in- creased $(\mathrm{n}=32)$, TMP yield was increased by 48.1 $\mathrm{g} / \mathrm{d}$. In those studies where milk production did not increase $(\mathrm{n}=43)$, TMP yield increased only $1.9 \mathrm{~g} / \mathrm{d}$. This was in spite of the fact that TMP percentage increased almost equally (0.069 and $0.062 \%$ for increased and decreased milk production, respectively). These observations support evaluating the RPM response based on TMP yield rather than on protein percentage as suggested by Vyas and Erdman (2009). A goal of this study was to investigate factors that affected milk response. Unfortunately, a highly predictive equation for a milk response to RPM feeding was not identified. One explanation for this is that most study cows were post-peak lactation, and they may have lacked the hormonal drive for greater milk production. There is evidence that milk yield is responsive when Lys and Met are infused in early lactation but not in mid or late lactation (Schwab et al., 1992). More studies with more carefully controlled lactation stages will be required before reliable predictions of milk responses to RPM are possible.

The relationship of Met and Lys as percentage of MP are particularly interesting for the present study compared with those presented by NRC (2001). The average weighted response in milk protein content $(0.07 \%)$ to added RPM in the present study was near the value $(0.09 \%)$ obtained when Met and Lys as percentage of MP were optimized by infusion in those studies cited by NRC. However, the Met as percentage of MP in the diets with added RPM in the present studies was predicted to be $2.35 \%$ compared with the recommended level of $2.50 \%$. Meanwhile, Lys as percentage of MP actually declined to $6.33 \%$ compared with a recommended level of $7.3 \%$. This would seem to contradict the study of Schwab et al. (1992) that suggested that Lys must be sufficient to obtain a significant response when infusing Met into the duodenum. However, feeding RPM may have different metabolic consequences than infusing DL-Met into the duodenum. These observations would seem to preclude Met and Lys as percentage of MP as factors in predicting responses to RPM. These observations do not mean that Lys amounts are not important in responses to added RPM, but they do suggest there are other moderating variables that may be of greater importance.

That predicted AA deficiency should affect the response size of production variables to RPM is logical. However, that RPM should increase milk production in animals predicted not to have a Met deficiency and decrease production in animals predicted to be Met deficient was surprising. Animals that were Met deficient responded with greater DMI and more TMP and milk fat (Table 7). Likewise, it may appear logical that breed should play some role in RPM response because 
of differences in genetic potential. However, it would seem that these effects should have been taken out as part of the random effect of study, yet breed effects remain. Holsteins responded with slightly less milk but with increased TMP percentage than non-Holsteins. Increases in TMP yield were not greatly different $(0.025$ vs. 0.029 for Holsteins and non-Holsteins, respectively). The reason for this is apparently that the response in Holsteins is moderated by NDF and CP concentration in the diet, whereas that in non-Holsteins is moderated by energy balance. In many respects, the effect of diet was the most interesting. It is clear that regardless of other factors, cows fed a diet based on alfalfa responded to RPM with greater milk production, whereas cows fed diets based on other forages responded with lower milk production. Alfalfa-fed cows also reduced milk fat percentage in response to RPM. Cows fed corn silagebased diets displayed the highest response in TMP percentage. These observations may signify differences in ruminal transformation of feed to energy and microbial protein as well as possible differences in RUP that models do not predict very well. This suggests that metabolizable Met may be acting in a pharmaceutical manner, or as a signal regulator, or that excess Met is being removed from the circulating blood by the liver when the needs of the mammary gland are satisfied. There is evidence for all 3 of these effects in the literature. High levels of Met have been shown to constrict blood flow to the mammary gland (Pisulewski et al., 1996). This may be responsible for the decrease in milk yield seen in some experiments. Recently, Cant et al. (2009) proposed that individual AA can upregulate TMP production without changing the supply of AA to the mammary gland. Although they have proposed this mechanism for AA other than Met, it may be a general regulatory phenomenon. Berthiaume et al. (2001, 2006) have shown the capacity of the liver to remove excess Met and the ability of the mammary gland to downregulate uptake of extra quantities of Met. Any one of these effects, or all 3 acting together, could explain the lack of a dosage response to RPM as documented in the present study.

The fact that RPM products elicited different directional differences in responses in terms of DMI and milk yield was unexpected because both products are based on DL-Met. It may be that decreases in DMI caused by feeding Mepron may be due to organoleptic factors as has been suggested by Benefield et al. (2009). Moderating factors detected for milk production are only for cows fed Mepron. For cows fed Mepron, the higher the $\mathrm{CP}$ content of the diet, the more milk produced when RPM was added to the diet. In the studies reviewed, cows fed Smartamine appeared to reduce milk production, although they responded with higher TMP percentage. The net result is that cows fed Mepron produced more than twice the amount of milk protein (37 vs. $16 \mathrm{~g}$ for Mepron and Smartamine, respectively). The explanation for this may lie in the release of the DL-Met. Constructed variables for DL-Met use (20.6 vs. $12.9 \%$ ), TMP per gram of product consumed (1.84 vs. $1.03)$, or milk nitrogen efficiency (27.3 vs. 26.2$)$ were not significantly different between Mepron and Smartamine, respectively. Although there are differences in coating between these products, it is difficult to believe that this small amount of material $(\sim 0.015 \%$ of DMI) could cause differences of the magnitude detected. Rather, the manner of release, because of damage to the coating system, effectiveness of the coating system, or in what portion of the intestine release occurs, would seem to be a more likely cause of this difference. This should be an area of fruitful study in the future.

If blood values of Met were indicators of ruminal inertness of RPM as proposed by Bach and Stern (2000), one would expect differences in the ability of these products to promote TMP output. Further, one would have expected a difference in response to DL-Met use or product use if Smartamine were truly more available as blood values clearly suggest (Blum et al., 1999; Sudekum et al., 2004). This was not observed, because Mepron appeared to promote more milk protein synthesis than Smartamine. This may mean that blood values reflect the rate of release of RPM rather than the level of protection. In fact, it could be postulated that as DL-Met release approaches utilization, blood values may not change at all. Or, as suggested above, the presence of increased arterial supply of RPM may be all that is required for the mammary gland to elicit a protein production response (Cant et al., 2009).

\section{CONCLUSIONS}

For this data set, the AC model (version 3.5.2) and the NRC (2001) model predicted Met and Lys flows, both in gram quantities and as percentage of MP, as well as total MP flow, quite closely. Rumen-protected Met increased TMP percentage and yield while slightly decreasing DMI and milk fat percentage and slightly increasing milk yield and milk fat yield. Status of Met, Lys, or other AA deficiency did not affect TMP percentage in response to RPM supplementation. Likewise, the amount of RPM fed did not appear to affect TMP response. Milk production changes in response to feeding RPM clearly have a large effect on TMP yield and the incorporation of DL-Met into TMP. Mepron and Smartamine functioned differently in terms of DMI, milk production, and TMP production. More research 
will be needed to adequately predict the most effective use of RPM and to determine the exact manner in which it functions.

\section{REFERENCES}

Armentano, L. E., S. J. Bertics, and G. A. Ducharme. 1997. Response of lactating cows to methionine or methionine plus lysine added to high protein diets based on alfalfa hay and heated soybeans. J. Dairy Sci. 80:1194-1199.

Arthur, W., Jr., W. Bennett Jr., and A. I. Huffcut. 2001. Conducting Meta-Analysis Using SAS. Lawrence Erlbaum Associates Inc., Publishers, Mahwah, NJ.

Bach, A., and M. D. Stern. 2000. Measuring resistance to ruminal degradation and bioavailability of ruminally protected methionine. Anim. Feed Sci. Technol. 84:23-32.

Benefield, B. C., R. A. Patton, M. J. Stevenson, and T. R. Overton. 2009. Evaluation of rumen-protected methionine and period length on performance of lactating dairy cows with Latin squares. J. Dairy Sci. 92:4448-4455.

Berthiaume, R., P. Dubreuil, M. Stevenson, B. W. McBride, and H. Lapierre. 2001. Intestinal disappearance and mesenteric and portal appearance of amino acids in dairy cows fed ruminally protected methionine. J. Dairy Sci. 84:194-203.

Berthiaume, R., M. C. Thivierge, R. A. Patton, P. Dubreull, M. Stevenson, B. W. McBride, and H. Lapierre. 2006. Effect of ruminally protected methionine on splanchnic metabolism of amino acids in lactating dairy cows. J. Dairy Sci. 89:1621-1634.

Beyer, M., A. Chudy, L. Hoffmann, W. Jentsch, W. Laube, K. Nehring, and R. Schiemann. 2003. Rostock Feed Evaluation System. Research Institute for the Biology of Farm Animals (FBN), Dummerstorf, Germany.

Blum, J. W., R. M. Bruckmaier, and F. Jans. 1999. Rumen-protected methionine fed to dairy cows: Bioavailability and effects on plasma amino acid pattern and plasma metabolite and insulin concentrations. J. Dairy Sci. 82:1991-1998.

Broderick, G. A., and R. E. Muck. 2009. Effect of alfalfa silage storage structure and rumen-protected methionine on production in lactating dairy cows. J. Dairy Sci. 92:1281-1289.

Broderick, G. A., M. J. Stevenson, and R. A. Patton. 2009. Effect of dietary protein concentration and degradability on response to rumen-protected methionine in lactating dairy cows. J. Dairy Sci. 92:2719-2728.

Broderick, G. A., M. J. Stevenson, R. A. Patton, N. E. Lobos, and J. J. Olmos Colmenero. 2008. Effect of supplementing rumen-protected methionine on production and nitrogen excretion in lactating dairy cows. J. Dairy Sci. 91:1092-1102.

Cant, J. P., N. G. Purdie, S. A. Burgos, C. A. Toerien, V. R. Osborne, and Y. H. Moon. 2009. Manipulation of milk synthesis with amino acids. Pages 1-9 Proc. Eastern Nutrition Conference, Anim. Nutr. Assoc. Canada, Quebec City, Canada.

Chilliard, Y., and M. Doreau. 1997. Influence of supplementary fish oil and rumen-protected methionine on milk yield and composition in dairy cows. J. Dairy Res. 64:173-179.

Davidson, S., B. A. Hopkins, J. Odle, C. Brownie, V. Fellner, and L. W. Whitlow. 2008. Supplementing limited methionine diets with rumen-protected methionine, betaine, and choline in early lactation Holstein cows. J. Dairy Sci. 91:1552-1559.

Doepel, L., D. Pacheco, J. J. Kennelly, M. D. Hanigan, I. F. Lopez, and H. Lapierre. 2004. Milk protein synthesis as a function of amino acid supply. J. Dairy Sci. 87:1279-1297.

Girard, C. L., H. Lapierre, J. J. Matte, and G. E. Lobley. 2005 Effects of dietary supplements of folic acid and rumen-protected methionine on lactational performance and folate metabolism of dairy cows. J. Dairy Sci. 88:660-670.

Kowalski, Z. M., P. M. Pisulewski, and M. Gorgulu. 2003. Effects of protected methionine and variable energy supply on lactational responses in dairy cows fed grass silage-based diets. J. Anim. Feed Sci. 12:451-464.
Kowalski, Z. M., P. M. Pisulewski, and M. Spanghero. 1999. Effects of calcium soaps of rapeseed fatty acids and protected methionine on milk yield and composition in dairy cows. J. Dairy Res. 66:475487.

Krober, T. F., M. Kreuzer, M. Senn, W. Langhans, and F. Sutter. 2000. Lactational and metabolic effects in cows of lysine and methionine added to a ration deficient according to the I.N.R.A. method. Arch. Anim. Nutr. 53:375-394.

Krober, T. F., F. Sutter, M. Senn, W. Langhans, and M. Kreuzer. 2001. Effects of supplying leucine and methionine to early lactating cows fed silage-concentrate based diets with a calculated deficiency in leucine and methionine. Anim. Res. 50:5-20.

Lapierre, H., D. Pacheco, R. Berthiaume, D. R. Ouellet, C. G. Schwab, P. Dubreuil, G. Holtrop, and G. E. Lobley. 2006. What is the true supply of amino acids for a dairy cow? J. Dairy Sci. 89(E Suppl.):E1-E14.

Lara, A., G. D. Mendoza, L. Landois, R. Barcena, M. T. SanchezTorres, R. Rojo, J. Ayala, and S. Vega. 2006. Milk production in Holstein cows supplemented with different levels of ruminally protected methionine. Livest. Prod. Sci. 105:105-108.

Lean, I. J., A. R. Rabiee, T. F. Duffield, and I. R. Dohoo. 2009. Invited review: Use of meta-analysis in animal health and reproduction: Methods and applications. J. Dairy Sci. 92:3545-3565.

Leonardi, C., M. Stevenson, and L. E. Armentano. 2003. Effect of two levels of crude protein and methionine supplementation on performance of dairy cows. J. Dairy Sci. 86:4033-4042.

Misciatteilli, L., V. F. Kristensen, M. Vestergaard, M. R. Weisbjerg, K. Sejrsen, and T. Hvelpund. 2003. Milk production, nutrient utilization and endocrine responses to increased postruminal lysine and methionine supply in dairy cows. J. Dairy Sci. 86:275-286.

NRC. 2001. Nutrient Requirements of Dairy Cattle. 7th rev. ed. Natl. Acad. Sci., Washington, DC.

Ordway, R. S., S. E. Boucher, N. L. Whitehouse, C. G. Schwab, and B. K. Sloan. 2009. Effects of providing two forms of supplemental methionine to periparturient Holstein dairy cows on feed intake and lactational performance. J. Dairy Sci. 92:5154-5166.

Overton, T. R., L. S. Emmert, and J. H. Clark. 1998. Effects of source of carbohydrate and protein and rumen-protected methionine on performance of cows. J. Dairy Sci. 81:221-228.

Overton, T. R., D. W. LaCount, T. M. Cicela, and J. H. Clark. 1996. Evaluation of a ruminally protected methionine product for lactating dairy cows. J. Dairy Sci. 79:631-638.

Papas, A. M., C. J. Sniffen, and T. V. Muscato. 1984a. Effectiveness of rumen-protected methionine for delivering methionine postruminally in dairy cows. J. Dairy Sci. 67:545-552.

Papas, A. M., J. L. Vicini, J. H. Clark, and S. Peirce-Sandner. 1984b. Effect of rumen-protected methionine on plasma free amino acids and production by dairy cows. J. Nutr. 114:2221-2227.

Patton, R. A. 2009. The strategic use of ruminally protected amino acids in dairy nutrition. Pages 39-51 in Proc. Florida Ruminant Nutrition Symposium, Univ. Florida, Gainesville.

Pisulewski, P. M., and Z. M. Kowalski. 1999a. The effect of protected lysine and methionine on milk yield and its composition in lactating dairy cows fed grass silage-based rations. J. Anim. Feed Sci. 8:341-353.

Pisulewski, P. M., and Z. M. Kowalski. 1999b. The effect of protected methionine on milk yield and in composition in lactating dairy cows fed grass silage-based diets. J. Anim. Feed Sci. 8:355-366.

Pisulewski, P. M., Z. M. Kowalski, and M. Gorgulu. 2002. Lactational responses to ruminally-protected methionine in cows fed a lowprotein grass silage based diet. J. Anim. Feed Sci. 11:189-203.

Pisulewski, P. M., H. Rulquin, J. L. Peyraud, and R. Verite. 1996. Lactational and systemic responses of dairy cows to postruminal infusions of increasing amounts of methionine. J. Dairy Sci. 79:1781-1791.

Polan, C. E., K. A. Cummins, C. J. Sniffen, T. V. Muscato, J. L. Vicini, B. A. Crooker, J. H. Clark, D. G. Johnson, D. E. Otterby, B. Guillaume, L. D. Muller, G. A. Varga, R. A. Murray, and S. B. Peirce-Sandner. 1991. Responses of dairy cows to supplemental rumen-protected forms of methionine and lysine. J. Dairy Sci. 74:2997-3013. 
Preynat, A., H. Lapierre, M. C. Thivierge, M. F. Palin, J. J. Matte, A. Desrochers, and C. L. Girard. 2009a. Effects of supplements of folic acid, vitamin B12 and rumen-protected methionine on whole body metabolism of methionine and glucose in lactating dairy cows. J. Dairy Sci. 92:677-689.

Preynat, A., H. Lapierre, M. C. Thivierge, M. F. Palin, J. J. Matte, A. Desrochers, and C. L. Girard. 2009b. Influence of methionine supply on the response of lactational performance of dairy cows to supplementary folic acid and vitamin B12. J. Dairy Sci. 92:16851695.

Pruekvimolphan, S., and R. R. Grummer. 2001. Lactational responses to sulfur-containing amino acids from feather meal or rumenprotected methionine. J. Dairy Sci. 84:2515-2522.

Rulquin, H., and L. Delaby. 1997. Effects of the energy balance of dairy cows on lactational responses to rumen-protected methionine. J. Dairy Sci. 80:2513-2522.

Rulquin, H., B. Graulet, L. Delaby, and J. C. Robert. 2006. Effect of different forms of methionine on lactational performance of dairy cows. J. Dairy Sci. 89:4387-4394.

Samuelson, D. J., S. K. Denise, R. Roffler, R. L. Ax, D. V. Armstrong, and D. F. Romagnolo. 2001. Response of Holstein and Brown Swiss cows fed alfalfa hay-based diets to supplemental methionine at two stages of lactation. J. Dairy Sci. 84:917-928.

Schmidt, J., P. Pipocz, E. Cenkvari, and J. Sipocz. 1999. Use of protected methionine (Mepron M85) in cattle. Acta Vet. Hung. 47:409-418.

Schwab, C. G., C. K. Bozak, N. L. Whitehouse, and V. M. Olson. 1992. Amino acid limitation and flow to the duodenum at four stages of lactation. 2. Extent of lysine limitation. J. Dairy Sci. 75:3503-3518.
Schwab, C. G., N. L. Whitehouse, A. M. McLaughlin, R. K. Kadariya, N. R. St-Pierre, B. K. Sloan, R. M. Gill, and J. C. Robert. 2001. Use of milk protein concentrations to estimate the "methionine bioavailability" of two forms of 2 hydroxy-4-methythio butanoic acid (HMB) for lactating cows. J. Dairy Sci. 84(Suppl. 1):35. (Abstr.)

Socha, M. T., D. E. Putnam, B. D. Garthwaite, N. L. Whitehouse, N. A Kierstead, C. G. Schwab, G. A. Ducharme, and J. C. Robert. 2005 Improving intestinal amino acid supply of pre- and postpartum dairy cows with rumen-protected methionine and lysine. J. Dairy Sci. 88:1113-1126.

Soder, K. J., and L. A. Holden. 1999. Lymphocyte proliferation response of lactating dairy cows fed varying concentrations of rumen-protected methionine. J. Dairy Sci. 82:1935-1942.

St-Pierre, N. R. 2001. Integrating quantitative findings from multiple studies using mixed model methodology. J. Dairy Sci. 84:741755 .

Sudekum, K. H., S. Wolffram, P. Ader, and J. C. Robert. 2004 Bioavailability of three ruminally protected methionine sources in cattle. Anim. Feed Sci. Technol. 113:17-25.

Vyas, D., and R. A. Erdman. 2009. Meta-analysis of milk protein yield responses to lysine and methionine supplementation. J. Dairy Sci. 92:5011-5018

Younge, B. A., J. J. Murphy, M. Rath, and B. K. Sloan. 2001. Effect of dietary absorbable methionine and lysine concentrations on milk production and composition of dairy cows offered grass-silage based diets. Ir. J. Agric. Food Res. 40:1-11. 